\title{
Person of the Issue: Wilhelm Wundt (1832-1920)
}

\author{
Mr. Ankit P. Patel*, Mr. Ansh Mehta**
}

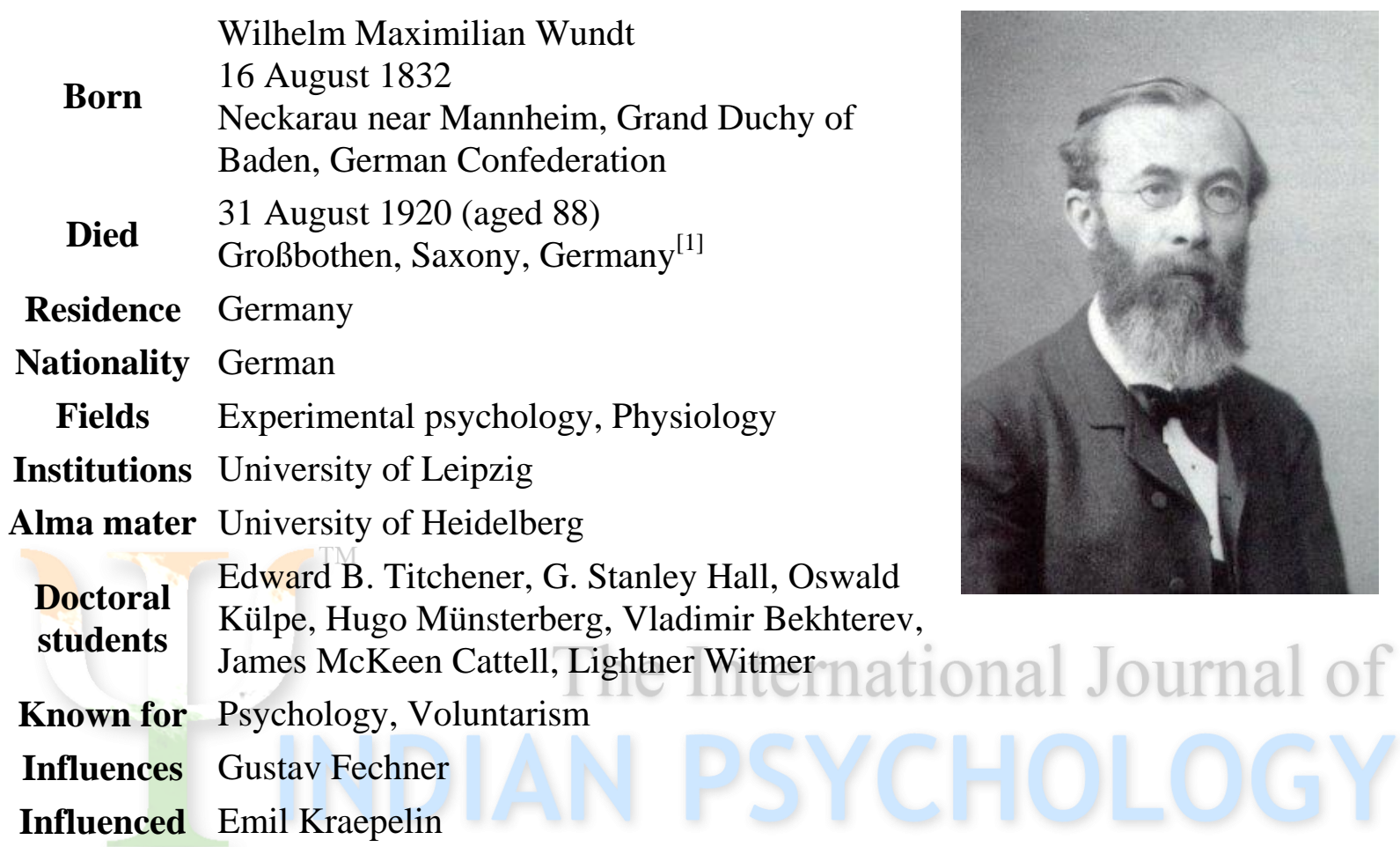

Wilhelm Wundt was born August 16th 1832 in Germany. He was a psychologist, physician, physiologist, professor, and philosopher. Many historians recognize him as the founding father of psychology, for he was the first to ever to titled as a psychologist. Actually, Wilhelm set psychology apart from philosophy and biology. In 1879, Wundt founded the first laboratory of psychological research at the University of Leipzig, located in Germany. This marked psychology as an individual field of mental studies. His laboratory enabled him to explore the religious beliefs (conceptual aspect), strange psychological behaviors, the practice of identification of mental disorders and finding damaged parts of the brain. While documenting his research, he learned that psychology was a separate science.

Wilhelm studied under many professors at the variety trio of Universities he attended. Some of these professors inspired him to write textbooks about his studies of Psychology. These works go by the names of Contributions to the Theory of Sense Perception (1858-62), Lectures on the Mind of Humans and Animals in 1863-1864, and Principles of Physiological Psychology. He founded this off of his research as an Inductive Philosopher, Professor of medical investigation, scientific psychology (His master field and what he was known for best.) and of physiology.

*\&**, M.A, Clinical Psychology, Dept. of Psychology, Sardar Patel Uni, Vallabh Vidhyanagar, Gujuarat 


\section{The International Journal of Indian Psychology: Volume: 01 | Issue: 04 | ISSN 2348-5396}

The Wundt had many inspirations throughout his life time that resulted in his development of the famous Psychology Lab. These inspirations were none other than his professors. (1856) shortly after his graduation in medicine from Heidelberg he studied with another famous physiologist. Dr. Johannes Peter Müller, one of his first inspirational colleagues, being Wundt's superior he much to offer to Wilhelm while they shared their knowledge of physiology (The branch of biology that deals with the normal functions of living organisms and their parts.). Years after his interaction with Müller, he met the love of his life, Sophie Mau in the University of Heidelberg. While away at his studies he would send her notes that are sacred in history as important historical documents containing some of his studies. The date is unknown for these two important characters but them too strongly empowered Wundt's thoughts and minds for they were a part of the experimental psychology establishment. Their names were Weber (17951878) and Fechner (1801-1887), who worked at Leipzig, inspired Wundt's interest in neuropsychology.

In 1879 the opening of the psychology lab was a success, more and more students piled in to learn the adaption to this branch of scientific mental studies. This lab was to emphasize psychology as a completely different branch from all else. Psychology was to be known as the scientific, analytical process of the human mind and its functions.

\section{Timeline}

- 1832 born at Neckarau/Mannheim, August 16th

- 1845 enters Bruchsal Gymnasium

- 1851-2 study of medicine at Tübingen

- 1852-5 study of medicine at Heidelberg

- 1853 first publication "on the sodium chloride content of urine"

- 1855 medical assistant at a Heidelberg clinic

- 1856 semester of study with J. Müller and DuBois-Reymond at Berlin; doctorate in medicine at Heidelberg; habilitation as Dozent in physiology; nearly fatal illness

- 1857-64 Privatdozent at the Physiological Institute, Heidelberg

- 1858 Beiträge zur Theorie der Sinneswahrnehmung; Helmholtz becomes director of the Heidelberg Physiological Institute

- 1862 first lectures in psychology

- 1863 Vorlesungen über die Menschen- und Tier-Seele

- 1864 made ausserordentlicher Professor; lectures on physiological psychology (published as [Wundt, 1874])

- 1870-71 Fails to be named Helmholtz's successor at Heidelberg; Army doctor in FrancoPrussian War

- 1873-4 Publishes Grundzüge der physiologischen Psychologie

- 1874 called to Zürich to the professorship in "inductive philosophy";

- 1875 called to Leipzig as professor

- 1879 founds the Institut für Experimentelle Psychologie, Leipzig; birth of son, Max

- 1881 Philosophische Studien founded 
The International Journal of Indian Psychology: Volume: 01 | Issue: 04 | ISSN 2348-5396

- 1880-83 Logik, 2 vols.

- 1886 Ethik, 3 vols.

- 1889 System der Philosophie, 2 vols.

- 1889-90 Rector of Leipzig University

- 1904 Völkerpsychologie, 2 vols.

- 1915 emeritus status

- 1917 retires from teaching; replaced by his student, Felix Krueger

- 1920 Dies at Grossbothen, near Leipzig, at the age of 88, August $31^{\text {st }}$

\section{Publications}

Wundt was extremely prolific in publications, of which this is a selection only.

- Die Lehre von der Muskelbewegung (The Patterns of Muscular Movement), (Vieweg, Braunschweig 1858).

- Die Geschwindigkeit des Gedankens (The Velocity of Thought) (Die Gartenlaube 1862, Vol 17, p. 263)

- Beiträge zur Theorie der Sinneswahrnehmung (Contributions on the Theory of Sensory Perception), (Winter, Leipzig 1862).

- Vorlesungen über die Menschen -und Tierseele (Lectures about Human and Animal Psychology), (Voss, Leipzig 1863/1864).

- Lehrbuch der Physiologie des Menschen (Text-book of Human Physiology), (Enke, Erlangen 1865).

- Die physikalischen Axiome und ihre Beziehung zum Causalprincip (Physical Axioms and their Bearing upon Causality Principles) (Enke, Erlangen 1866).

- Handbuch der medicinischen Physik (Handbook of Medical Physics), (Enke, Erlangen 1867)

- Grundzüge der physiologischen Psychologie (Principles of Physiological Psychology), (Engelmann, Leipzig 1874) (has been revised and republished several times ${ }^{[22]}$ )

- Untersuchungen zur Mechanik der Nerven und Nervenzentren (Researches upon the Mechanisms of Nerves and Nerve-Centres), 1876

- Logik. Eine Untersuchen der Principien der Erkenntniss und der Methoden Wissenschafticher Forschung (Logic. An investigation into the principles of knowledge and the methods of scientific research), (Enke, Stuttgart $1880 \& 1883$ ), 3 Volumes and vol. 4

- Essays, (Engelmann, Leipzig 1885).

- $\quad$ Ethik (Ethics), (Enke, Stuttgart 1886)

- System der Philosophie (System of Philosophy), (Engelmann, Leipzig 1889).

- Grundriss der Psychologie (Outline of Psychology), (Engelmann, Leipzig 1896).

- Völkerpsychologie (Social Psychology), 10 Volumes, (Engelmann, Leipzig 1900 to 1920)

○ 1, 2. Die Sprache (Language), Pt 1, 2. (1900)

- 3. Die Kunst (Art). (1908)

- 4, 5, 6. Mythos und Religion (Myth and Religion), Pt 1, 2, 3. (1910, 1914,)

- 7, 8. Die Gesellschaft (Society), Pt 1, 2. (1917) 
The International Journal of Indian Psychology: Volume: 01 | Issue: 04 | ISSN 2348-5396

○ 9. Das Recht (Right). (1918)

- 10. Kultur in der Geschichte (Culture in History). (1920)

- Kleine Schriften (Shorter Writings), 3 Volumes, (Engelmann, Leipzig 1910).

- Einleitung in die Psychologie (Introduction to Psychology), (Engelmann, Leipzig 1911).

- Probleme der Völkerpsychologie (Problems of Social Psychology), (Wiegandt, Leipzig 1911).

- Elemente der Völkerpsychologie (The Elements of Social Psychology), (Kröner, Leipzig 1912).

- Reden und Aufsätze (Addresses and Extracts), (Kröner, Leipzig 1913).

- Sinnliche und übersinnliche Welt (The Sensory and Supersensory World), (Kröner, Leipzig 1914).

- $\quad$ Über den wahrhaften Krieg (About the Real War), (Kröner, Leipzig 1914).

- Die Nationen und ihre Philosophie (Nations and Their Philosophies), (Kröner, Leipzig 1915).

- Erlebtes und Erkanntes (Experience and Realization), (Kröner, Stuttgart 1920).

- Philosophische Studien (the first journal of psychology), 1871

\section{Wundt's works in English}

1974 The Language of Gestures. Ed. Blumenthal, A.L. Berlin: De Gruyter

1973 An Introduction to Psychology. New York: Arno Press

1969? Outlines of Psychology. 1897. Tr. Judd, C.H. St. Clair Shores, MI: Scholarly Press

1916 Elements of folk-psychology. Tr. Schaub, E.L. London: Allen

1901 The Principles of Morality and the Departments of the Moral Life. Trans. Washburn, M.F. London: Swan Sonnenschein; New York: Macmillan

$1896^{2}$ Lectures on human and animal psychology. Creighton, J.G., Titchener, E.B., trans. London: Allen. Translation of Wundt, 1863

$1893^{3}$ Principles of physiological psychology. Titchener, E.B., trans. London: Allen. Translation of Wundt, 1874. [New York, 1904]

\section{Reference:}

1. Butler-Bowdon, Tom. 50 Psychology Classics, (2007): p. 2.

2. Carlson, Neil and Heth,C.Donald"Psychology the Science of Behaviour". Pearson Education Inc,2010 p. 18

3. Carpenter, Shana K (August 2005). "Some neglected contributions of Wilhelm Wundt to the psychology of memory.". Psychological reports 97 (1): 63-73. doi:10.2466/PR0.97.5.63-73. PMID 16279306.

4. Georg Lamberti: Wilhelm Maximilian Wundt 1832-1920.Leben, Werk und Persönlichkeit in Bildern und Texten.Deutscher Psychologen Verlag, Berlin 1995, ISBN 3-925559-83-3. 
The International Journal of Indian Psychology: Volume: 01 | Issue: 04 | ISSN 2348-5396

5. Steinberg, H (November 2001). "[The psychologist and philosopher Wilhelm Wundt and a dedication by his student Emil Kraepelin]". Der Nervenarzt 72 (11): 884. PMID 11758098

6. Titchener, E.B. (1921). Wilhelm Wundt. The American Journal of Psychology, 32(2). Retrieved from http://www.jstor.org.myaccess.library.utoronto.ca/stable/1413739

7. Titchner, E.B. 28 November 1970. "Wilhelm Wundt." The American Journal of Psychology 296(7683). http://www.jstor.org/stable/1413739

8. Ziche, P (1999). "Neuroscience in its context. Neuroscience and psychology in the work of Wilhelm Wundt.". Physis; rivista internazionale di storia della scienza 36 (2): 407-29. PMID 11640242.Smith, R (November 1982). "Wilhelm Wundt resurrected.". British journal for the history of science 15 (51 Pt 3): 285-91. doi:10.1017/S0007087400019361. PMID 11611088.
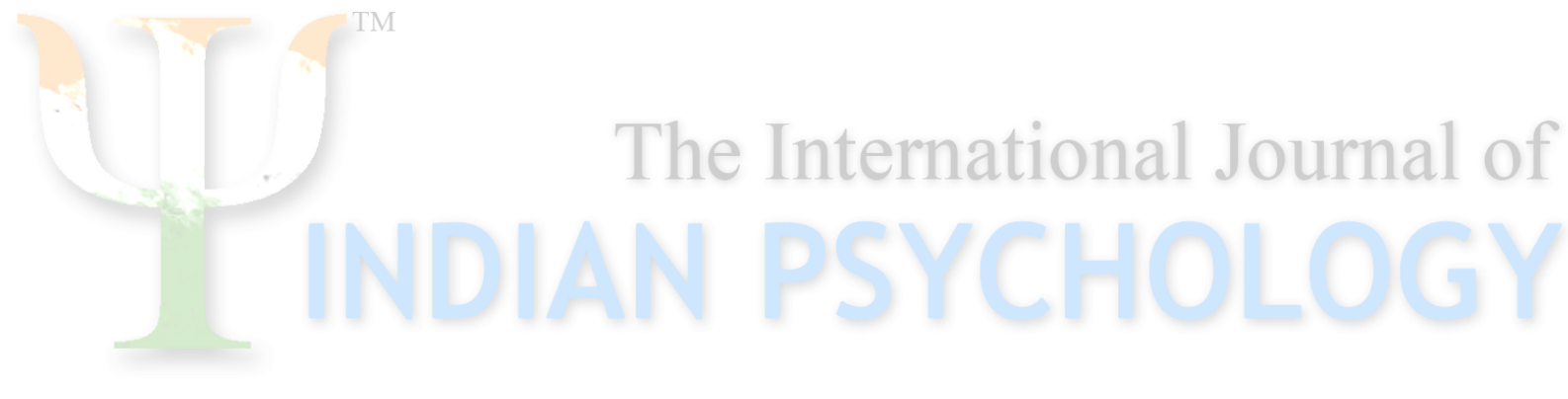